\title{
Loss of Estrogen Receptor 1 Enhances Cervical Cancer Invasion
}

\author{
Yali Zhai, ${ }^{*}$ Guido T. Bommer, ${ }^{\dagger \neq}$ Ying Feng, ${ }^{\dagger \neq}$ \\ Alexandra B. Wiese, ${ }^{*}$ Eric R. Fearon, ${ }^{* \dagger}$ \\ and Kathleen R. Cho*†‡ \\ From the Departments of Pathology, ${ }^{*}$ Internal Medicine, ${ }^{\dagger}$ and the \\ Comprehensive Cancer Center, ${ }^{\ddagger}$ The University of Michigan \\ Medical School, Ann Arbor, Michigan
}

If left untreated, some cervical high-grade squamous intraepithelial lesions will progress to invasive squamous cell carcinoma (SCC), but the molecular events conferring invasive potential remain poorly defined. In prior work, we identified 48 genes that were downregulated in SCCs compared with high-grade squamous intraepithelial lesions and normal squamous epithelia. In this study, a functional screening strategy was used to identify which of these genes regulate cervical cancer cell invasion. Two independent squamous epithelial cell lines were transduced with a library of short hairpin RNAs targeting the differentially expressed genes and tested for invasion of the chick chorioallantoic membrane. PCR was used to recover specific short hairpin RNAs from cells that invaded the chorioallantoic membrane. Constructs targeting estrogen receptor 1 (ESR1) were highly enriched in the invasive cells. The short hairpin RNAmediated inhibition of ESR1 in SCC- and precancerderived cell lines increased invasiveness in both in vivo and in vitro assays. Conversely, restoration of ESR1 expression in ESR1-negative cervical cancer cells reduced cell invasiveness. Loss of ESR1 expression was found to accompany cervical cancer progression in an analysis of primary normal cervix, low grade squamous intraepithelial lesions, high-grade squamous intraepithelial lesions, and SCC specimens. Molecular mechanisms underlying down-regulation of ESR1 in invasive cervical carcinomas appear to be complex and likely heterogeneous. Our findings indicate that loss of ESR1 has a major role in mediating cervical cancer invasion and progression. (Am J Pathol 2010, 177:884-895; DOI: 10.2353/ajpath.2010.091166)

Cervical cancer is the second most prevalent cancer in women worldwide, accounting for nearly a half million new cases and 274,000 deaths each year. ${ }^{1}$ Although cervical cytology screening has greatly reduced cervical cancer incidence and mortality in developed countries, cervical cancer remains a major cause of cancer-related mortality in developing countries, particularly in sub-Saharan Africa, Latin America, the Caribbean, and portions of south Asia. Even in developed countries, the cost and morbidity associated with management of cervical cancer precursor lesions, referred to as low-grade and highgrade squamous intraepithelial lesions (LSILs and HSILs, respectively) remain substantial. If left untreated, upwards of 10 to $15 \%$ of high-grade pre-invasive lesions will progress to invasive squamous cell carcinoma (SCC), while nearly a third will regress. ${ }^{2,3}$ However, because morphological assessment alone does not allow distinction of those HSILs likely to progress from those that will regress spontaneously, surgical excision of HSILs remains the clinical standard of care. ${ }^{4}$ In light of these considerations, there is substantial interest in identifying molecular mediators of progression from noninvasive cervical cancer precursor lesions to invasive carcinoma. Some factors might also prove to be useful biomarkers of progression risk.

To identify genes whose differential expression is linked to progression from HSIL to invasive carcinoma, we previously used high density oligonucleotide arrays (Affymetrix HG_U133A) to compare gene expression in pre-invasive and invasive cervical SCCs. ${ }^{5}$ We identified 48 genes that were at least twofold down-regulated in invasive carcinomas compared with HSILs and normal squamous epithelia. In the current study, we used a functional screening strategy to identify which of these genes likely serve as negative regulators of cervical cancer cell invasion. A library of short hairpin (sh)RNAs tar-

Supported by the Specialized Program of Research Excellence (SPORE) in Cervical Cancer grant P50 CA098252, National Cancer Institute.

Accepted for publication March 30, 2010.

Supplemental material for this article can be found on http://ajp. amjpathol.org

Current address for G.T.B.: De Duve Institute, Universite Catholique de Louvain, Bruxelles, Belgium.

Address reprint requests to Kathleen R. Cho, M.D., Department of Pathology, University of Michigan Medical School, 1506 BSRB, 109 Zina Pitcher Place, Ann Arbor, Ml 48109-2200. E-mail: kathcho@umich.edu. 
geting differentially expressed genes was used to transduce two independent cell lines that lacked invasive properties in the chick chorioallantoic membrane (CAM). Transduced cells were placed on the CAM and shRNAs were recovered from invasive cells using PCR. We found that shRNA-mediated depletion of estrogen receptor 1 (ESR1, also known as estrogen receptor $\alpha$ or $\mathrm{ER} \alpha$ ) in cervical cancer- and precancer-derived cell lines increased invasiveness in in vitro assays and into the chick CAM. Restoration of ESR1 expression in ESR1-negative cervical cancer cells reduced cell invasiveness. Immunohistochemical analysis of primary normal cervix, LSIL, HSIL, and SCC specimens showed loss of ESR1 expression during cervical cancer progression. We also explored several potential molecular mechanisms underlying down-regulation of ESR1 in invasive cervical carcinomas. Our findings support an important role of ESR1 in mediating cervical cancer invasion and progression.

\section{Materials and Methods}

\section{Cell Lines and Cell Culture}

Seven cervical carcinoma-derived cell lines C33A, C-4II, ME180, CaSki, MS751, HT-3, and HeLa were obtained from the American Type Culture Collection (Manassas, VA). The HPV16-immortalized keratinocyte cell line 8217 was a gift from P. Hawley Nelson (Bethesda, MD). NMU$\mathrm{T} 1$, an HPV18-immortalized keratinocyte cell line transformed by nitroso-methyl-urea, was a gift from J. K. McDougall (Fred Hutchinson Cancer Research Center, Seattle, WA). ${ }^{6,7}$ CIN612 (derived from grade 1 cervical intraepithelial neoplasia-CIN1 [also known as low grade squamous intraepithelial lesion; LSIL]) was a gift of K. De Geest (Rush Medical College, Chicago, IL). ${ }^{8,9}$ ME180 and HT-3 cells were cultured in McCoy's 5A medium (Life Technologies, Inc. Gaithersburg, MD) with 10\% fetal bovine serum (Life Technologies). CaSki cells were cultured in RPMI 1640/10\% fetal bovine serum. Keratinocyte-derived cells (NMU-T1, 8217, and CIN612) were cultured in keratinocyte growth medium (KGM-2, Lonza, Walkersville, MD). All other cell lines were maintained in Dulbecco's modified Eagle's medium with $10 \%$ fetal bovine serum.

\section{Human Papillomavirus Detection and Typing}

A total of 27 invasive SCCs of the cervix, 13 HSILs, 12 LSILs and 22 normal cervix, formalin-fixed, paraffin-embedded, tissue samples were analyzed with approval from the Institutional Review Board of the University of Michigan Medical School (IRBMED 2002-0430). Sections were deparaffinized, then manually microdissected to enrich for epithelial cells. DNA was extracted using a DNA digestion buffer containing $2 \mathrm{mg} / \mathrm{ml}$ proteinase $\mathrm{K}$. Human papillomavirus (HPV) detection and typing were performed using PCR amplification of HPV DNA, followed by direct sequencing. The GP5+/GP6+, L1C1/LIC2, and/or L1C2-M consensus primers were used for HPV
DNA detection. ${ }^{10,11}$ All HPV-negative samples were confirmed by a second PCR assay and adequate DNA quality was verified by successful amplification of HPRT1 sequences from the same DNA samples. PCR products were purified with the GENECLEAN III Kit (MP Biomedicals, Solon, $\mathrm{OH}$ ) and directly sequenced. DNA sequences were compared with GenBank sequences using the BLAST Program at the National Center for Biotechnology Information. In selected cases, HPV types were further confirmed by HPV E7 type-specific PCR using published primer sequences. ${ }^{12}$

\section{Generation of shRNA Library Targeting Genes Down-Regulated in Invasive Carcinomas Relative to Noninvasive Precursor Lesions}

pGIPZ plasmids allowing expression of shRNAs predicted to target genes previously shown to be downregulated in invasive cervical cancers relative to high grade squamous intraepithelial lesions and normal squamous epithelia ${ }^{5}$ were obtained from the shRNA core of University of Michigan (Human pGIPZ collection, Open Biosystems, Huntsville, AL). shRNA pools were generated by combining an equal amount of each plasmid. The pooled shRNA pGIPZ plasmids or pGIPZ nonsilencing shRNAmir control plasmid (Open Biosystems) were cotransfected with a lentiviral packaging vector into 293T cells. The cervical cancer-derived cell line MS751 and precancer-derived cell line CIN612 were transduced with lentiviral supernatant. Stable polyclonal lines were generated by selection in puromycin at a concentration of 0.8 to $1.25 \mu \mathrm{g} / \mathrm{ml}$.

\section{Lentiviral shRNAmir-Mediated Knockdown of ESR1 and EZH2 Expression}

To knock down ESR1 expression in cell lines CIN612 and MS751, two additional shRNAs targeting ESR1 were obtained from the shRNA core of University of Michigan (Human pGIPZ collection, Open Biosystems, Huntsville, AL). Stable polyclonal CIN612 and MS751 cell lines expressing three independent ESR1-specific shRNAmir or control shRNAmir were transduced with lentiviral supernatant and grown in the presence of puromycin at a concentration of 0.8 to $1.25 \mu \mathrm{g} / \mathrm{ml}$. To knockdown EZH2 expression in HeLa, SiHa and C33A cells, cells were transduced with two independent EZH2 shRNAmir and control shRNAmir. Stable polyclonal lines were generated by selection in puromycin at a concentration of 1 to $1.25 \mu \mathrm{g} / \mathrm{ml}$.

\section{Chick Embryo CAM Invasion Assay}

Fertilized eggs were purchased from local poultry farms (Michigan State University, Lansing, MI or Bilbie Aviaries, Ann Arbor, MI). The embryos were incubated for 11 days at 37 to $38^{\circ} \mathrm{C}$ with $60 \%$ humidity. Preparation of CAMs has been previously described. ${ }^{5}$ Briefly, to grow tumor masses, $2.5 \times 10^{6}$ cells in $30 \mu$ l of Hank's Balanced Salt 
Solution were applied on the CAM. After 2 to 5 days, the tumor masses and underlying CAM were excised and fixed with $4 \%$ paraformadehyde in PBS overnight at $4^{\circ} \mathrm{C}$. Frozen sections were cut from CAM tissues after immersion in 30\% sucrose. The frozen sections were stained with mouse anti-laminin antibody $(3 \mathrm{H} 11$, diluted 1:10; Developmental Studies Hybridoma Bank, University of lowa, lowa City, IA) for 2 hours, then incubated with Alexa Fluor 594 conjugated goat anti-mouse IgG secondary antibody (1:500; Invitrogen, Carlsbad, CA) for 60 minutes at room temperature. Sections were mounted with Vectashield mounting media with 4',6-diamidino-2-phenylindole (Vector Laboratories, Burlingame, CA), monitored under a fluorescent microscope (Olympus BX-51, Microscopy \& Image Analysis Laboratory, University of Michigan, MI) and photographed with an Olympus DP-70 high resolution digital camera (Microscopy \& Image Analysis Laboratory). Serial sections were also prepared and stained with H\&E for light microscopic examination.

\section{Matrigel Transmembrane Invasion Assay}

Transwell invasion chambers (BD Biosciences, Bedford $\mathrm{MA}$ ) with $8-\mu \mathrm{m}$ pore inserts were used to perform in vitro invasion assays. Five $\times 10^{4}$ cells were plated in the upper chamber of 24-well invasion chambers and allowed to invade across the Matrigel-coated membrane for 48 to 72 hours. Complete KGM-2 or 10\% fetal bovine serum medium as a chemoattractant was added to the bottom well. After noninvading cells were removed from the top of each membrane with wet cotton swabs, invading cells attached to the bottom of the membrane were fixed and stained with 4,6-diamidino-2-phenylindole. The number of cells that penetrated the membrane was obtained by determining the mean number of cells in five randomly selected $\times 20$ fields. Experiments were performed in triplicate, and the assays were repeated at least once to verify results.

\section{Recovery of shRNA Sequences from Cells Invading the Chick CAM}

MS751 and CIN612 cells transduced with pooled shRNAs were placed on CAMs as described above. Cells invading the CAM were scraped from H\&E stained frozen sections using manual microdissection. DNA was extracted from invasive cells using standard techniques, and PCR was performed using forward and reverse primers in the pGIPZ vector flanking the shRNA sequences. PCR products were subcloned into the PCR 2.1-TOPO vector (Invitrogen). Fifty clones from each DNA sample were sequenced to characterize specific shRNA sequences present in the invasive cells. For comparison purposes, DNA was also isolated from CIN612 cells transduced with pooled shRNAs, but without placement on the CAM.

\section{RNA Isolation and Quantitative Reverse Transcription-PCR}

Total RNA from each cell line was extracted using standard procedures (Trizol reagent, Invitrogen). cDNA was synthesized from $4 \mu \mathrm{g}$ total RNA using a high capacity cDNA reverse transcription kit (Applied Biosystems, Foster City, CA). Quantitative reverse transcription (qRT)PCR was performed with an ABI Prism 7700 Sequence Analyzer using SYBR green fluorescent protocol (Applied Biosystems). Each reaction was run in duplicate. qRTPCR reactions for target and internal control genes were performed in separate tubes. The comparative threshold cycle $\left(C_{\mathrm{T}}\right)$ method was used for the calculation of amplification-fold as specified by the manufacturer. PCR was performed in $25 \mu$ l reactions containing $1 \times$ SYBR Green PCR mix (Applied Biosystems), $200 \mathrm{nmol} / \mathrm{L}$ of each primer, and $10 \mathrm{ng}$ of first strand CDNA. The PCR conditions were $50^{\circ} \mathrm{C}$ for 2 minutes, $95^{\circ} \mathrm{C}$ for 10 minutes, followed by 40 cycles of $95^{\circ} \mathrm{C} 15$ seconds, and $60^{\circ} \mathrm{C} 1$ minute. Each reaction was set up in duplicate and two separate measurements were performed.

\section{Immunohistochemical Analysis of ESR1 and EZH2 in Primary Cervical Tissues}

A tissue microarray composed of formalin fixed, paraffinembedded human cervical tissues (17 squamous cell carcinomas, 5 HSILs, 8 LSILs, and 8 normal cervical epithelia) has been previously described. ${ }^{5}$ In addition, 10 squamous cell carcinomas, 8 HSILs, 4 LSILs and 14 normal cervix samples from the Surgical Pathology archives of the University of Michigan Health System (not included in the tissue microarray) were evaluated. Tissues were analyzed with approval from the institutional review board of the University of Michigan Medical School (IRBMED 2002-0430). Five-micron tissue microarray and tissue sections were mounted on Probe-On slides (Fisher Scientific, Itasca, IL), deparaffinized in xylene, and then rehydrated in distilled $\mathrm{H}_{2} \mathrm{O}$ through graded alcohols. Antigen retrieval was performed by microwaving the slides in citrate buffer $(\mathrm{pH}$ 6.0, Biogenex, San Ramon, CA) for 10 minutes. Endogenous peroxidase activity was quenched by incubation with $3 \%$ hydrogen peroxide in methanol, and then sections were blocked with $1.5 \%$ normal horse serum for 30 minutes. Sections were incubated with mouse monoclonal anti-EZH2 (1:250 dilution, BD Biosciences, San Jose, CA) or mouse monoclonal anti-ESR1 (1:50 dilution, Dako, Carpinteria, CA) overnight at $4^{\circ} \mathrm{C}$. Slides were washed in PBS, then incubated with a biotinylated horse anti-mouse secondary antibody for 30 minutes at room temperature. Antigenantibody complexes were detected with the avidin-biotin peroxidase method using Vector diaminobenzidine as a chromogenic substrate (Vectastain ABC kit, Vector Laboratories). Immunostained sections were lightly counterstained with hematoxylin then examined by light microscopy. Immunostaining was scored on a four tiered scale for intensity $(-$, absent; \pm , weak; + , moderate; ++ , strong) in the cell nucleus. 


\section{ESR1, EZH2, Snail and Slug Expression Vector Construction and Transfection}

Full length ESR1 cDNA (spanning nucleotides 235 to 2022, GenBank accession \#: NM-000125.3) and full length EZH2 cDNA (spanning nucleotides 167 to 2422, GenBank accession \#: NM-004456) were generated by RT-PCR using total RNA from MCF7 and HeLa cells, respectively. PCR primers were designed to include a Flag epitope tag at the gene product's C-terminus. PCR products were subcloned into the retroviral vector PPGSCMV-CITE-neo and the CDNA sequence of individual clones verified by DNA sequencing. Flag-tagged expression constructs for SNAl1 (Snail) and SNAI2 (Slug) cDNAs in the same vector have been previously described. ${ }^{13}$ Selected cell lines were transduced with retroviral supernatant from amphotrophic Phoenix cells transfected with vector alone or vector with each cDNA. Stable polyclonal lines were generated by selection in G418 at a concentration of 0.8 to $1 \mathrm{mg} / \mathrm{ml}$. After 1 week, the $\mathrm{G} 418$ concentration was reduced to 0.4 to $0.5 \mathrm{mg} / \mathrm{ml}$, and expression of Flag-tagged protein was confirmed by Western blot analysis.

\section{Western Blot}

Parental and stably transduced cells were lysed in cold radioimmunoprecipitation assay lysis buffer containing proteinase inhibitors (complete proteinase inhibitors, Roche Applied Science, Indianapolis, IN). Whole-cell lysates were analyzed by Western blotting with rabbit polyclonal anti-ESR1 antibody (Santa Cruz Biotechnology, Santa Cruz, CA) at 1:5000; anti-EZH2 antibody (BD Biosciences) at 1:5000; rabbit monoclonal anti-Slug or rat monoclonal anti-Snail antibody (Cell Signaling, Danvers, MA) at 1:1000 dilution. Expression of $\beta$-actin was used as a loading control and was detected with anti-actin monoclonal antibody (Sigma, St, Louis, MO).

\section{ESR1 Promoter Methylation Analysis: Bisulfite Sequencing}

Genomic DNA was extracted from cultured cells and frozen tumor tissue with the Puregene DNA purification kit (Gentra Systems, Minneapolis, MN). Five hundred ng of DNA was bisulfite treated with EZ DNA Methylation-Gold kit (Zymo Research., Orange, CA) per the manufacturer's instructions. The bisulfite-treated DNA was amplified using PCR primers that were designed according to the MethPrimer program developed by Li and Dahiya. ${ }^{14}$ Primer sequences used to amplify the ESR1 promoter fragment were 5'-AGATTAGTATTTAAAGTTGGAGGTT-3' (forward) and 5'-ATATAAAAAATCATAATCATAATCC-3' (reverse). The 288 bp PCR products, including $27 \mathrm{CpG}$ sites in the first exon of ESR1, were cloned into the TOPO TA Cloning vector (Invitrogen) after gel purification. Methylation status was determined by sequencing using a vector-specific primer and $\mathrm{BiQ}$ analyzer software (http://biq-analyzer. bioinf. mpi-sb.mpg.de/).
The number of methylated CpGs at each specific site was divided by the number of clones analyzed ( $n=8)$, to yield a value representing the percentage of methylation at each site.

\section{Statistical Analysis}

Statistical analyses were performed using SPSS 10.0 (SPSS, Inc., Chicago, IL). For transwell invasion assays, statistical differences in cell invasion between groups were determined by the Mann-Whitney U-test. For the qRT-PCR studies, statistical differences of expression between groups were calculated with the Student's t-test. Values were expressed as means \pm SD. In all cases, values of $P<0.05$ were considered to be significant.

\section{Results}

\section{Functional Screen for Identification of Genes Involved in Progression from Intraepithelial (Noninvasive) Squamous Carcinoma Precursor Lesions to Invasive Carcinoma}

To identify genes whose differential expression is linked to cervical cancer progression, in prior work we compared gene expression in laser capture microdissected squamous epithelial samples from 10 normal cervices, 7 HSILs, and 21 SCCs using high-density oligonucleotide microarrays (Affymetrix U133A). ${ }^{5}$ Forty-eight genes were at least twofold down-regulated in invasive carcinomas compared with HSILs and normal squamous epithelia $\left(P<0.001\right.$; see Figure 1 in ref. ${ }^{5}$ and Supplemental Table $\mathrm{S} 1$ at $h$ ttp//ajp.amipathol.org). We wished to perform a functional screen to determine which of these genes, when down-regulated, might underlie progression of noninvasive precursor lesions to invasive carcinoma. We queried the Open Biosystems Human pGIPZ shRNA plasmid collection available from the University of Michigan's shRNA core facility for genes on our list with a minimum of two shRNAs available for gene targeting. Nineteen of the 48 genes down-regulated in invasive carcinomas relative to HSILs appeared to have at least two available shRNA plasmids; thirteen of these had three available shRNAs (Table 1). One of two clones targeting the $D A C H$ gene was found to contain incorrect sequence, so it was omitted. The shRNA plasmids were pooled and used to generate lentivirus expressing the collection of 50 shRNAs. CIN612, derived from a noninvasive cervical carcinoma precursor lesion, and MS751 cervical carcinoma cells were transduced with the pooled shRNAs or nonsilencing shRNA control lentivirus. The invasiveness of cells transduced with pooled shRNA or control lentivirus was examined with the chick CAM assay. This in vivo assay closely mimics invasion of neoplastic epithelial cells through the basement membrane and into underlying cervical stroma.

Both CIN612 and MS751 cells transduced with pooled shRNAs consistently showed increased invasion of the CAM after 4-day incubation (Figure 1, A and B). In con- 
A
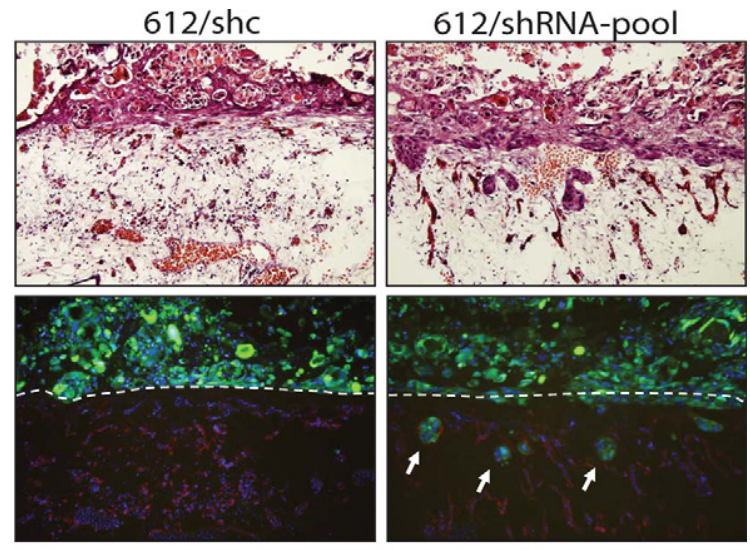

B
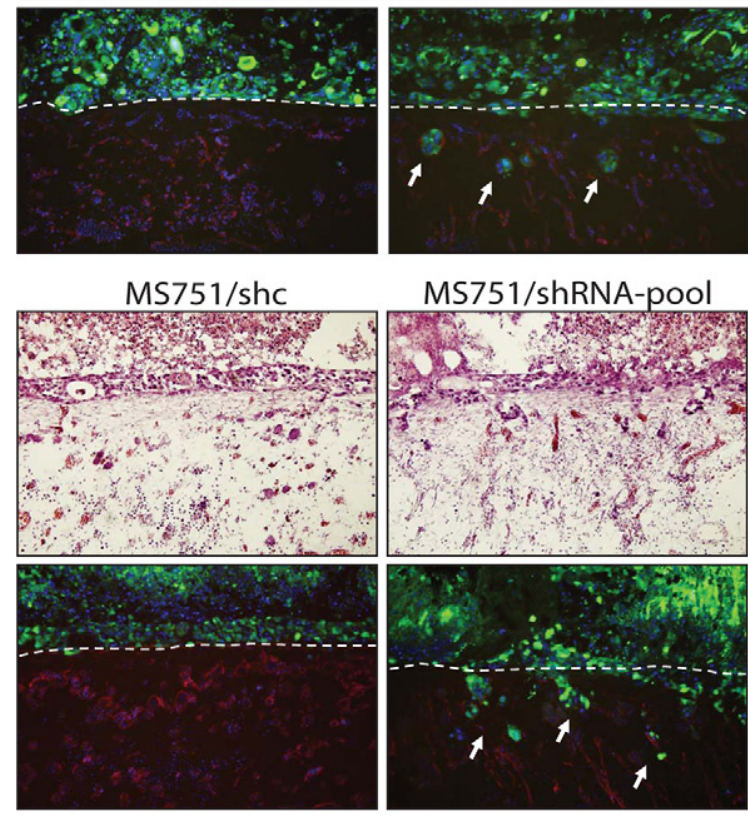

MS751/shRNA-pool

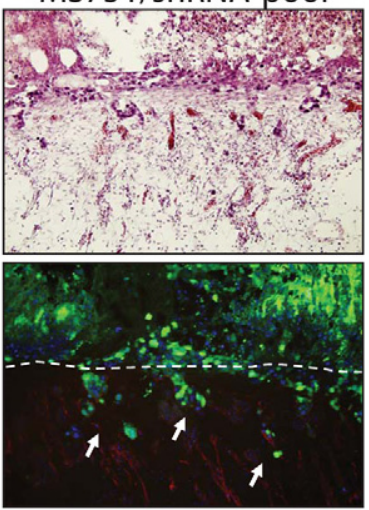

C

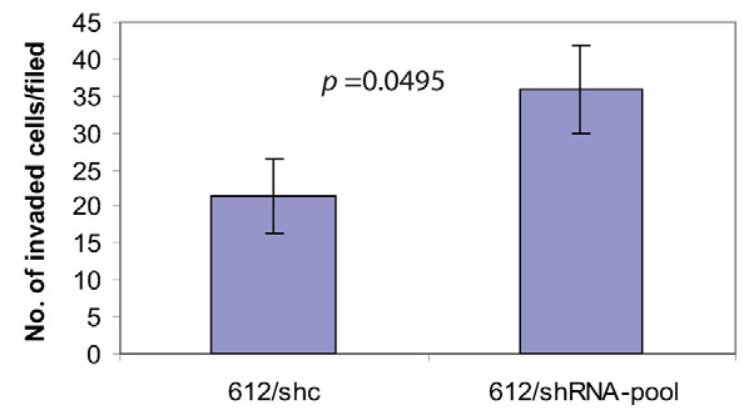

Figure 1. Pooled shRNAs targeting genes down-regulated in invasive cervical cancers relative to pre-invasive lesions enhance cervical epithelial cell invasion. CIN612 (A) and MS751 (B) cells transduced with control (shc) or pooled shRNA lentivirus were implanted on chick CAMs and harvested after 4-day incubation. Serial sections of CAM tissue were evaluated by light microscopy (H\&E, top row) or fluorescence microscopy (immunostaining for chick laminin: Red, DAPI: Blue, or GFP: Green; bottom row). The CAM surface is demarcated by dashed white lines and arrows indicate cells invading the CAM. Original magnification, $\times 200$. C: CIN612 cells transduced with pooled shRNA lentivirus showed increased invasion through Matrigelcoated transwells compared with matched control shRNA (shc) cells $(P=$ 0.0495 , Mann-Whitney $U$-test). Mean and SD of cells counted in five fields from each of two independent experiments are shown.

trast, cells transduced with control (shc) lentivirus showed no or only minimal invasion of the CAM. Effect of the pooled shRNAs on invasiveness of CIN612 and MS751 cells was further assessed using Matrigel-coated transwell inserts. CIN612 cells transduced with the pooled shRNAs showed significantly increased invasion through Matrigel compared with cells transduced with the non-silencing control lentivirus (Figure 1C) while no difference in invasion through Matrigel was observed in
MS751 cervical carcinoma cells transduced with pooled shRNAs versus control (data not shown).

To recover the specific shRNAs likely contributing to increased invasiveness of CIN612 and MS751 cells transduced with pooled shRNAs, cells invading the CAM were isolated from cryosections by manual microdissection, then subjected to DNA extraction. To demonstrate that selected shRNAs were truly enriched in the invasive cell population, DNA was extracted in parallel from the CIN612 cells that had not been grown on the CAM. PCR was performed using primers in flanking vector sequences, then PCR products were cloned and 50 individual clones from each DNA sample were sequenced to identify the shRNAs expressed in the invasive cells (Table 2). We found that shRNA sequences targeting 10 of the 19 candidate genes were recovered from both CIN612 and MS751 cells invading the CAM. shRNAs targeting ESR1 and $A R$ were recovered most frequently from invasive cells of both cell lines and these shRNAs were enriched in the invasive cells relative to CIN612 cells without prior placement on the CAM. We focused the remainder of our studies on ESR1, since some prior data had suggested that ESR1 might be down-regulated in invasive cervical carcinomas relative to their noninvasive precursor lesions. ${ }^{15-17}$

\section{Expression of ESR1 Is Low in Most Invasive Cervical Carcinomas and Carcinoma-Derived Cell Lines Compared with Noninvasive Precursor Lesions}

ESR1 transcript and protein expression were evaluated in several cervical carcinoma-derived cell lines, HPV-immortalized keratinocyte cell lines and CIN612 cells using qRT-PCR and immunoblotting, respectively. ESR1 mRNA and protein levels were low or undetectable in most of the cancer cell lines but were readily detectable in ME180 and MS751 carcinoma cells and CIN612 cells derived from a cervical squamous intraepithelial lesion (Figure 2, $A$ and B). Immunohistochemical staining of primary cervical tissues was also performed to confirm ESR1 downregulation in invasive carcinomas compared with noninvasive precursor lesions and normal cervical squamous epithelium. ESR1 expression was evaluated in 74 primary cervical tissue samples including 27 SCC, $13 \mathrm{HSIL}, 12$ LSIL, and 22 normal cervical epithelia. Loss of ESR1 expression accompanied cervical cancer progression, with the vast majority of invasive carcinomas showing loss of ESR1 expression (Figure 2C). For the data shown in Figure 2C, $(-)$ or $(+/-)$ staining was considered negative, while $(+)$ or $(++)$ was considered positive. The four-tiered ESR1 immunostaining score for each individual tumor is shown in Supplemental Table S2 (at http// ajp.amjpathol.org). As noted in previous studies, ESR1 expression in normal epithelium was primarily observed in the basal portions of the epithelium. ${ }^{15}$ To determine whether HPV presence or particular type correlated with ESR1 expression, the HPV status of each tissue sample was determined using PCR amplification of DNA samples using one 
Table 1. List of Genes Down-Regulated in Invasive Cervical Carcinomas, and Number of Independent shRNAs Contributing to shRNA Library

\begin{tabular}{|c|c|c|c|c|}
\hline $\begin{array}{l}\text { Probe-set } \\
\text { name }\end{array}$ & Gene symbol & Unigene title & $\begin{array}{c}\text { Fold } \\
\text { change }\end{array}$ & $\begin{array}{c}\text { shRNA } \\
\text { clone No. }\end{array}$ \\
\hline $\begin{array}{l}\text { 213661_at } \\
\text { 212768_s_at } \\
\text { 205225_at } \\
\text { 205862_at } \\
\text { 213994_s_at } \\
\text { 209291_at } \\
\text { 208399_s_at } \\
\text { 204115_at } \\
211621 \text { at } \\
\text { 204719_at } \\
\text { 210609_s_at } \\
\text { 201312_s_at } \\
\text { 205898_at } \\
\text { 209243_s_at } \\
\text { 205471_s_at } \\
\text { 206295_at } \\
212230 \text { at } \\
\text { 205186_at } \\
\text { 206101_at } \\
\text { Total }\end{array}$ & $\begin{array}{l}\text { DKFZP586H2 } \\
\text { OLFM4/GW112 } \\
\text { ESR1 } \\
\text { GREB1 } \\
\text { SPON1 } \\
\text { ID4 } \\
\text { EDN3 } \\
\text { GNG11 } \\
\text { AR } \\
\text { ABCA8 } \\
\text { TP53/3 } \\
\text { SH3BGRL } \\
\text { CX3CR1 } \\
\text { PEG3 } \\
\text { DACH } \\
\text { IL18 } \\
\text { PPAP2B } \\
\text { DNALI1 } \\
\text { ECM2 }\end{array}$ & $\begin{array}{l}\text { DKFZP586H2123 protein } \\
\text { differentially expressed in hematopoietic lineages } \\
\text { estrogen receptor } 1 \\
\text { GREB protein } \\
\text { spondin 1, (f-spondin) extracellular matrix protein } \\
\text { inhibitor of DNA binding 4, dominant negative helix-loop-helix protein } \\
\text { endothelin } 3 \\
\text { guanine nucleotide binding protein } 11 \\
\text { androgen receptor } \\
\text { ATP-binding cassette, sub-family A (ABC1), member } 8 \\
\text { tumor protein p53 inducible protein } 3 \\
\text { SH3 domain binding glutamic acid-rich protein like } \\
\text { chemokine (C-X3-C) receptor } 1 \\
\text { paternally expressed } 3 \\
\text { dachshund homolog (Drosophila) } \\
\text { interleukin } 18 \text { (interferon-gamma-inducing factor) } \\
\text { phosphatidic acid phosphatase type } 2 \mathrm{~B} \\
\text { dynein, axonemal, light intermediate polypeptide } 1 \\
\text { extracellular matrix protein } 2 \text {, female organ and adipocyte specific }\end{array}$ & $\begin{array}{l}-8.3 \\
-7.6 \\
-5.0 \\
-4.5 \\
-4.0 \\
-3.4 \\
-3.1 \\
-2.9 \\
-2.9 \\
-2.9 \\
-2.8 \\
-2.6 \\
-2.5 \\
-2.5 \\
-2.3 \\
-2.3 \\
-2.2 \\
-2.2 \\
-2.0\end{array}$ & $\begin{array}{r}3 \\
3 \\
3 \\
3 \\
3 \\
3 \\
2 \\
3 \\
3 \\
3 \\
3 \\
2 \\
2 \\
3 \\
1 \\
2 \\
2 \\
3 \\
3 \\
50\end{array}$ \\
\hline
\end{tabular}

or more sets of consensus primers, followed by direct sequencing of the PCR products. We identified no correlation between HPV status or HPV type with loss of ESR1 expression (Supplemental Table S2 at http//ajp.amjpathol.org).

\section{shRNA-Mediated Knockdown of ESR1 Increases Invasiveness of MS751 and CIN612 Cells}

We wished to determine whether down-regulation of ESR1 alters invasiveness of cervical epithelial cells. Endogenous ESR1 levels were knocked down in MS751 and

Table 2. List of Genes Targeted by shRNAs Recovered from shRNA Pool-Transduced CIN612 and MS751 Cells Invading the Chick CAM

\begin{tabular}{lccc}
\hline & \multicolumn{3}{c}{ Recovered clone numbers } \\
\cline { 2 - 3 } \multicolumn{1}{c}{ Gene name } & After CAM assay & Before CAM \\
\cline { 2 - 4 } & $612 /$ pool & MS751/pool & assay $612 /$ pool \\
\hline ESR1 & 12 & 9 & 3 \\
AR & 13 & 12 & 3 \\
GREB1 & 2 & 4 & 2 \\
DKFZP586H2123 & 1 & 6 & 1 \\
DACH1 & 2 & 4 & 0 \\
DNALI 1 & 4 & 1 & 3 \\
OLFM4 & 4 & 1 & 0 \\
ECM2 & 1 & 2 & 6 \\
ID4 & 1 & 2 & 3 \\
IL18 & 1 & 1 & 2 \\
GNG11 & 3 & 0 & 2 \\
CX3CR1 & 0 & 1 & 2 \\
SH3BGRL & 0 & 1 & 3 \\
PPAP2B & 0 & 1 & 2 \\
EDN3 & 0 & 0 & 2 \\
TP53/3 & 0 & 0 & 3 \\
PEG3 & 0 & 0 & 1 \\
ABCA8 & 0 & 0 & 1 \\
Vector/unknown & 6 & 5 & 11 \\
& 50 & 50 & 50 \\
\hline
\end{tabular}

CIN612 cells using three different lentiviral shRNA vectors targeting ESR1 to better exclude off-target effects (Figure 3A). Invasiveness of cells transduced with ESR1targeting shRNAs versus nonsilencing control lentivirus was assessed in vitro using Matrigel coated transwells and in vivo using the chick CAM. ESR1 knockdown in CIN612 cells resulted in statistically significant increased invasion through Matrigel (shc versus sh1, $P=0.05$; shc versus sh2, $P<0.01$; shc versus sh $3, P=0.01$; Student's $t$-test) compared with cells transduced with the control lentivirus (data not shown). Furthermore, MS751 and CIN612 cells stably transduced with shRNAs targeting ESR1 consistently showed enhanced invasion of the chick CAM compared with matched cells transduced with nonsilencing control lentivirus following a 3- to 4-day incubation (Figures 3, B and C). We also wished to determine whether restoration of ESR1 expression in cervical carcinoma cells with low endogenous levels of ESR1 would reduce their invasiveness. We transduced SiHa and HeLa cervical carcinoma cells with retrovirus expressing full length ESR1 cDNA and empty vector control. Restored expression of ESR1 resulted in reduced invasion of both cell lines through Matrigel-coated transwells, although only data from SiHa achieved statistical significance (Figure 4, A-C). Neither SiHa nor HeLa cells with forced expression of ESR1 showed reduced invasion of the chick CAM (data not shown), suggesting other factors may cooperate with ESR1 to suppress invasion of some cervical cancer cells in vivo.

\section{Mechanisms Contributing to Loss of ESR1 Expression during Cervical Cancer Progression}

DNA methylation of the ESR1 (ER $\alpha)$ CpG island has been linked to loss of ER $\alpha$ expression in breast cancers. ${ }^{18,19}$ ESR1 promoter methylation has also been reported in cervical cancers. ${ }^{20,21}$ To examine whether methylation of 


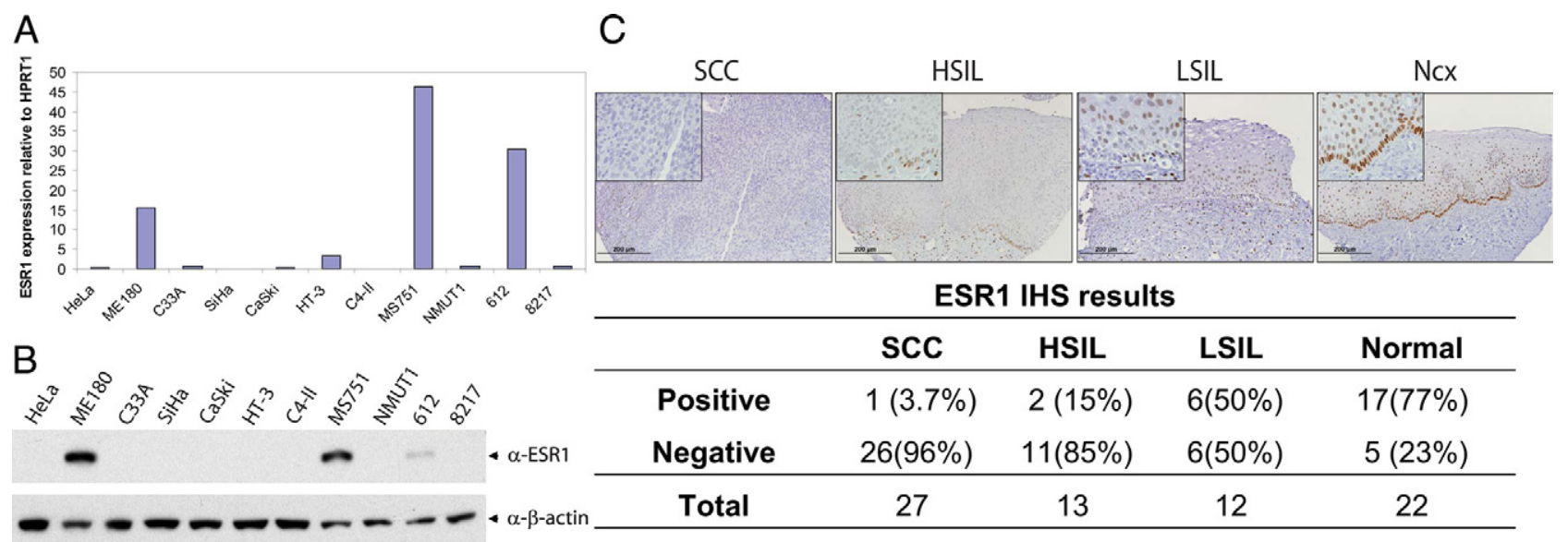

Figure 2. ESR1 transcript and protein expression is reduced in most cervical cancer cell lines and primary cervical carcinomas. Real-time RT-PCR (A) and Western blot (B) show markedly reduced or undetectable expression of ESR1 transcripts and protein, respectively, in most cervical cancer cell lines. C: Representative photomicrographs from immunohistochemical analysis of ESR1 expression in primary cervical tissue samples shows progressive loss of during cervical cancer progression. Original magnification, $\times 400$ (insets). Immunostaining data from all SCCs, HSILs, LSILs and normal cervix tissues are summarized at bottom.

the ESR1 promoter correlated with loss of ESR1 expression in cervical cancer, we analyzed the methylation status of 5 ER-negative (HeLa, C33A, SiHa, CaSki, and HT-3) and 3 ER-positive (ME180, MS751, CIN612) cervical cancer cell lines and 10 ER-negative primary invasive squamous cell carcinomas using bisulfite-sequencing (Figure 5, A-B). We found at least 15\% methylated CpGs in the ER-negative lines, while two of the three ER-positive lines were virtually devoid of methylated CpGs in the same region evaluated. None of the 10 ER-negative primary cervical carcinomas showed significant ESR1 promoter methylation. Hence, while methylation of CpGs in the ESR1 promoter may contribute to ESR1 silencing in a subset of cervical cancer cell lines, this mechanism does not appear to play a major role in ESR1 down-regulation in most primary tumor samples. ESR1 expression in ME180 is surprisingly high given the rather substantial rate of ESR1 promoter methylation identified in these cells. Notably, there are several studies in the published literature in which the extent of ESR1 promoter methylation is at odds with protein expression. For example, Lapidus et $\mathrm{al}^{19}$ showed that a sizeable fraction of ER+ breast tumors have extensive ER promoter methylation. Similar findings were obtained by Hori et $\mathrm{al}^{22}$ in their analysis of ESR1 promoter methylation and protein expression in endometrial tissue samples. In addition, ESR1 has two promoters, one more distal and the other more proximal. We only evaluated the CpG island associated with the more proximal promoter. At least one study found that the highest degree of negativity for $\mathrm{ER} \alpha$ expression was seen in breast tumors with methylation at both promoters. ${ }^{23}$

Recent studies suggest that the E-cadherin repressor Snail mediates epithelial-to-mesenchymal transition in
A

Figure 3. shRNA-mediated knockdown of endogenous ESR1 increases invasion of CIN612 and MS751 cells. A: Western blot analysis of lysates from indicated cells after stable transduction with lentiviruses expressing three independent shRNAs (sh1, sh2 and sh3) targeting ESR1 and one control shRNA (shc). ESR1 expression was detected with an anti-ESR 1 antibody and detection of $\beta$-actin was used as a loading control. CAM assays showing increased invasiveness of CIN612 (B) and MS751 (C) cells transduced with three independent shRNAs after a 4-day incubation. Top rows: serial sections of CAM tissue stained with H\&E; Bottom rows: Immunofluorescence for chick laminin: Red, DAPI: Blue, GFP: Green The CAM surface is demarcated by dashed white lines and arrows indicate cells invading the CAM. Original magnifications, $\times 200$.

\section{B}

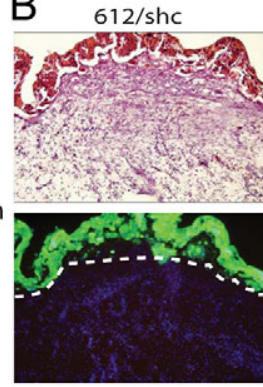

C

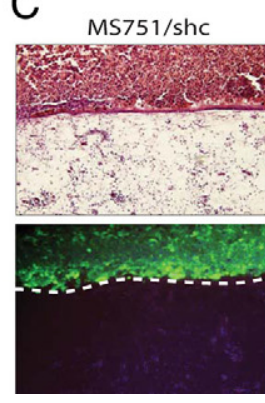

$612 / \mathrm{sh} 1$

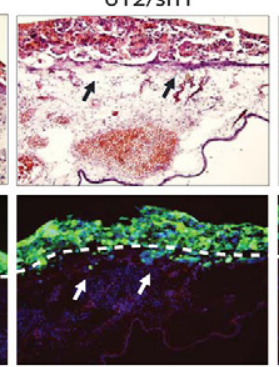

MS751/sh1
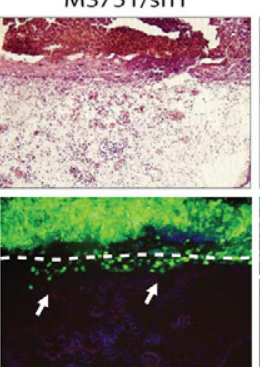

$612 / \mathrm{sh} 2$

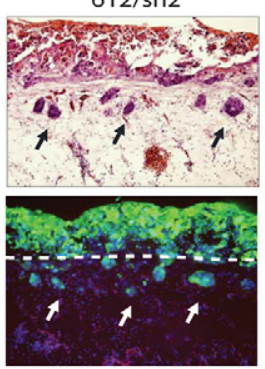

$612 / \mathrm{sh} 3$
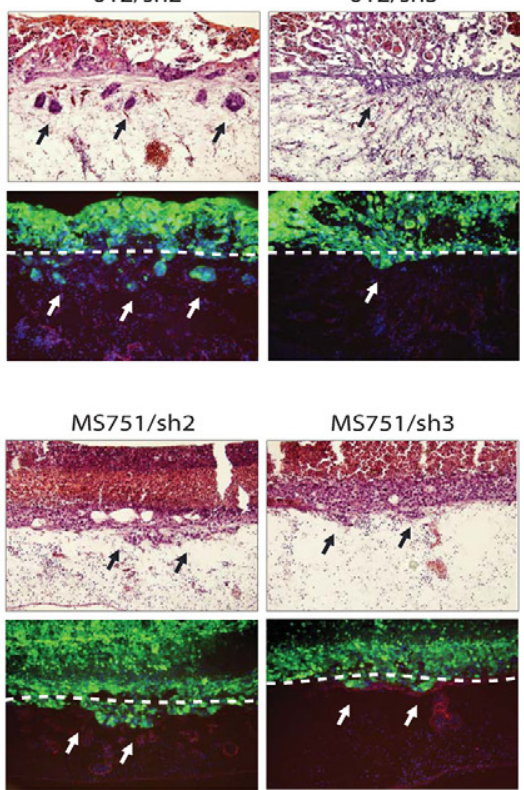

MS751/sh3

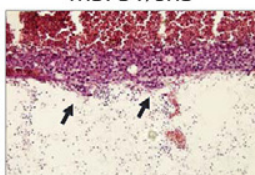

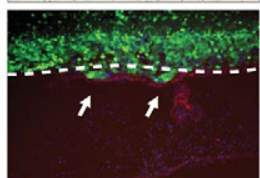



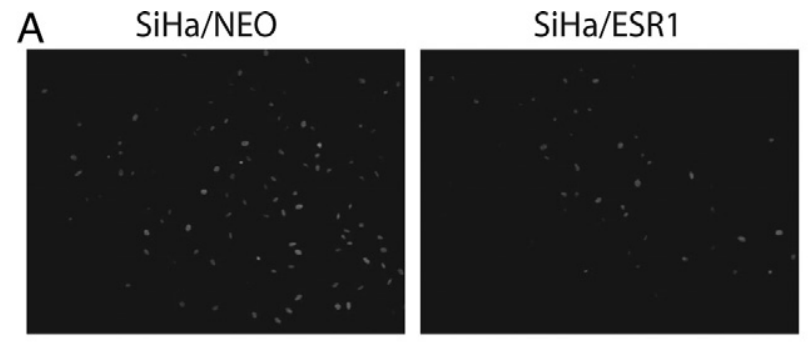

B

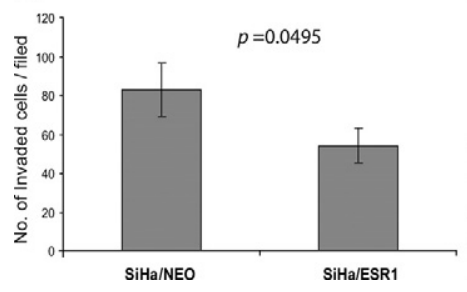

C

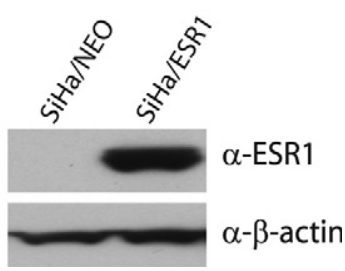

Figure 4. Ectopic expression of ESR1 inhibits invasion of SiHa cells through Matrigel coated transwells. A: Representative photomicrographs of control (Neo) and ESR1 expressing SiHa cells penetrating the membrane. B: $\mathrm{SiHa}$ ESR1 cells show decreased invasion compared with matched control ( $\mathrm{SiHa}$ neo) cells after stable transduction with replication-deficient retroviruses expressing full-length ESR1 or control retrovirus. Mean and SD of cells counted in five fields from each of three independent experiments are shown ( $P=0.0495$ based on Mann-Whitney $U$-test). C: Western blot analysis of lysates from SiHa cells transduced with ESR1 or control retrovirus. ESR1was detected with an anti-ESR1 antibody and detection of $\beta$-actin was used as a loading control.

breast cancers, in part through repression of ESR1. ${ }^{24}$ To demonstrate whether down-regulation of ESR1 in cervical cancers might be a consequence of repression by Snail (SNA/1) or Slug (SNA/2), we evaluated endogenous levels of these proteins in our panel of cervical cancer and keratinocyte-derived cell lines. We did not find an inverse correlation between ESR1 and either Snail or Slug expression (Figure 6A). Overexpression of Snail in ESR1expressing CIN612 and MS751 cells had no effect on ESR1 transcripts and protein and overexpression of Slug in the same cell lines had only modest effects on ESR1 expression (Figure 6B).

To explore other potential mechanisms that might contribute to down-regulation of ESR1 expression in cervical cancers, we sought to identify transcripts with strong inverse correlation with ESR1 using our gene expression database (see Supplemental Table S3 at http//ajp. amjpathol.org for list of genes). Expression levels of EZH2 (enhancer of zeste homolog 2), which encodes a polycomb group repressor protein, showed strong inverse correlation with ESR1 (correlation coefficient $r=-0.6723$ ). Notably, recent studies have shown that increased levels of EZH2 are associated with negative ER expression and disease progression in breast cancers, ${ }^{25-27}$ and EZH2 expression has been shown to be activated by HPV16 E7 at the transcriptional level through E7-mediated release of $\mathrm{E} 2 \mathrm{~F}$ from $\mathrm{Rb}$ and related pocket proteins. ${ }^{28} \mathrm{We}$ examined EZH2 protein expression in our panel of cervical cancer cell lines by Western blot. EZH2 was detectable in all cell lines and showed no obvious correlation with ESR1 expression (Figure 7A). EZH2 expression was substantial in MS751, one of the two lines used in the original functional screen. In contrast, in primary cervical tissue

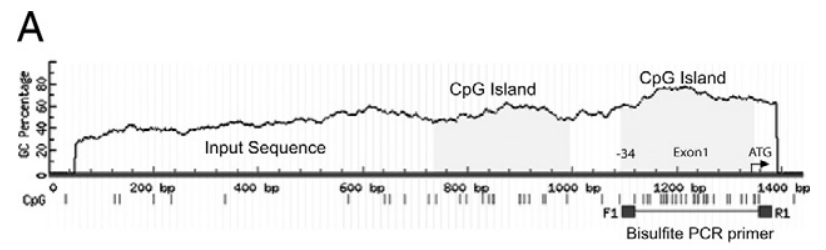

B
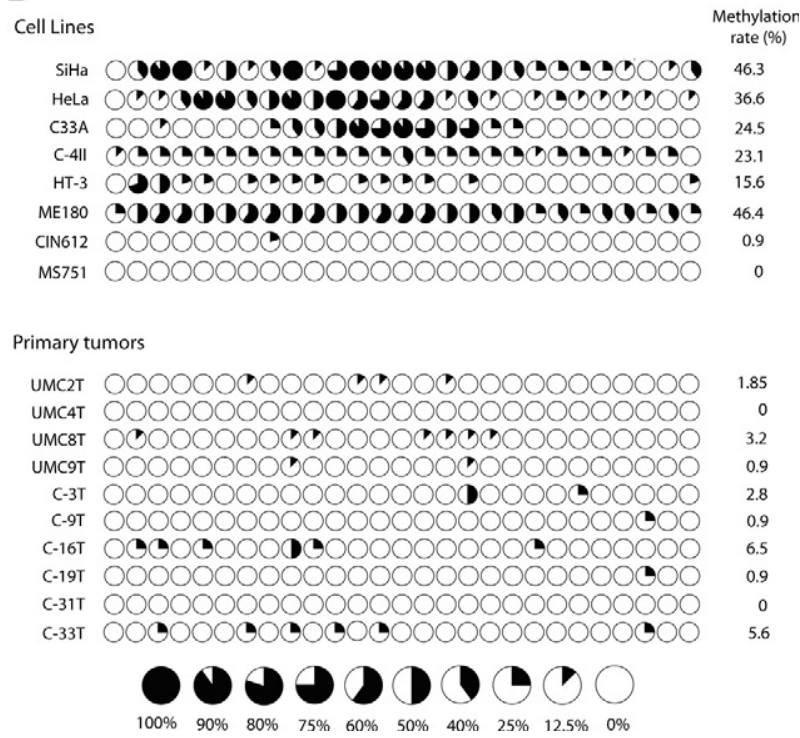

1.85

0

3.2

0.9

2.8

0.9

5.6

Figure 5. Methylation status of ESR1 in cervical cancer-derived cell lines and primary cervical squamous carcinomas. A: Schematic diagram showing CpG islands in the ESR1 promoter and first exon, and primer location. B: Summary of ESR1 methylation status by bisulfite sequencing. Twenty-seven CpGs for sample are shown; each circle represents the methylation status of an individual CPG dinucleotide as indicated at panel bottom.

specimens, ESR1 and EZH2 expression was inversely correlated $\left(r=-0.527, P=1.19^{\mathrm{E}-06}\right)$ based on immunohistochemical staining (Figure 7B and Supplemental Table S2 at http//ajp.amjpathol.org). We wished to determine whether knockdown of endogenous EZH2 in ER-negative cell lines could restore ESR1 expression. shRNA-mediated depletion of EZH2 expression in C33A, HeLa, and $\mathrm{SiHa}$ cells led to a 1.5- to 2.5-fold increase of ESR1 transcripts based on q-RT-PCR (Figure 7C) but ESR1 protein remained undetectable by Western blotting (data not shown). Forced expression of EZH2 in ESR1-expressing cervical cancer cells failed to result in down-regulation of ESR1 expression (data not shown). Hence, although ESR1 and EZH2 expression are inversely correlated in primary cervical tissues and EZH2 knockdown in cervical cancer-derived cell lines modestly increases ESR1 transcripts, elevated EZH2 expression is not likely to be the sole mechanism underlying ESR1 down-regulation in invasive cervical cancer cells.

\section{Discussion}

In this study, we used a functional screening strategy to identify ESR1 as an important inhibitory factor in cervical cancer cell invasion. ESR1 encodes a ligand-dependent transcription factor that plays a key role in the development and differentiation of cells in the breast and female 
A

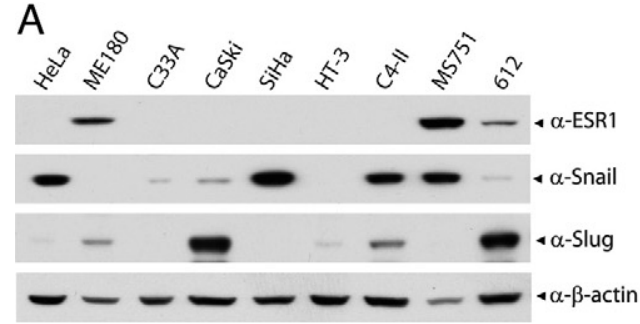

Figure 6. ESR1 expression is not modulated by Snail or Slug in cervical cancer cells. A: Western blot analysis of endogenous Snail, Slug and ESR1 in cervical cancer cell lines shows no inverse correlation between ESR1 and either Snail or Slug expression. $\beta$-actin was used as a loading control. B: CIN612 and MS751 cells stably transduced with replication-deficient retroviruses expressing full-length Snail, Slug or control retrovirus (neo) were subjected to real-time RT-PCR (left panel) and Western blot (right panel) analysis to determine the effect on ESR1 transcripts and protein, respectively. RT-PCR data represent mean $+\mathrm{SD}$ derived from three independent experiments, each performed in duplicate.
B
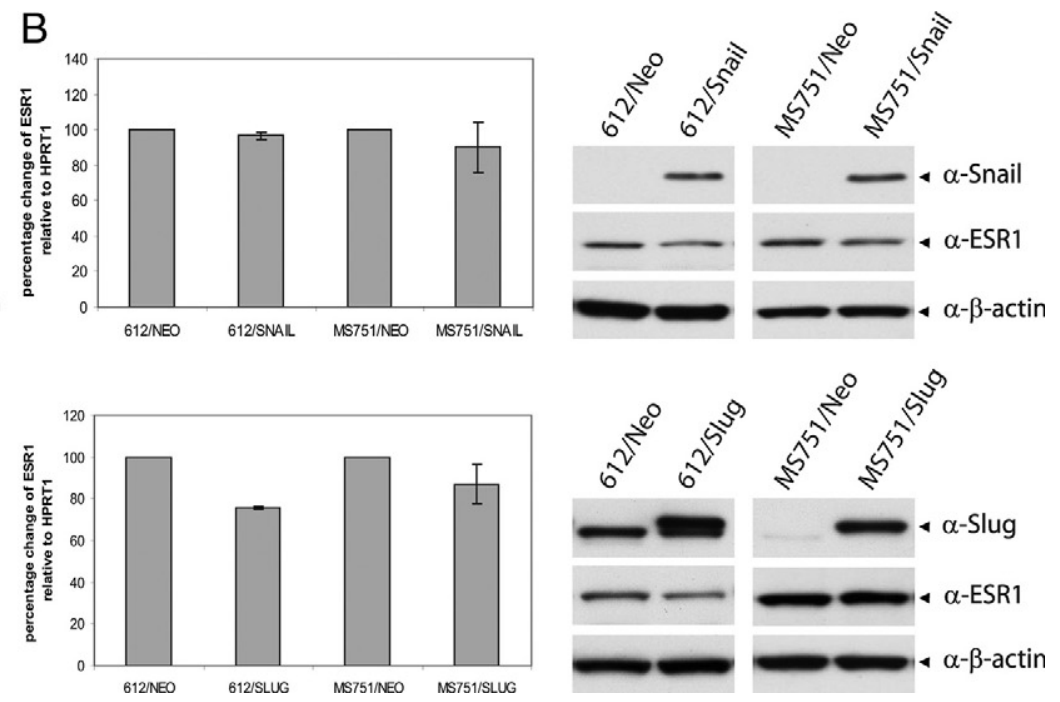

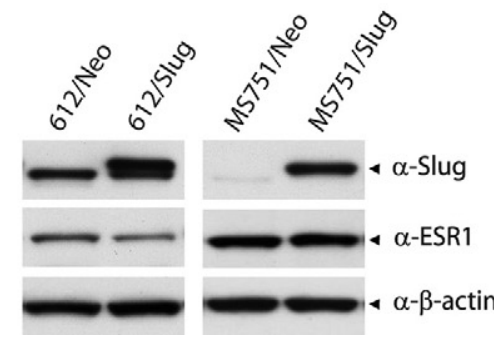

reproductive tract. In the presence of ligand, ESR1 may inhibit invasion through mechanism(s) involving transcriptional activation of estrogen response element-regulated target genes such as E-cadherin, which increases cell-cell adhesion, and $\alpha 1$-antichymotrypsin, which decreases matrix degradation. ${ }^{29}$ ESR1 may also inhibit invasion through mechanism(s) independent of ligand binding, but involving protein-protein interactions between as yet unknown nuclear factors with the first zinc finger of the receptor. ${ }^{29}$

Although much remains to be learned about the molecular mechanisms by which ESR1 inhibits cancer cell invasion, clinico-pathological studies have shown that loss of ESR1 in selected cancer types is associated with cancer progression. ${ }^{30,31}$ In breast and endometrial carcinoma cells, overexpression of ESR1 reduced their invasiveness, ${ }^{32,33}$ and stable re-introduction of functional ESR1 in ESR1-negative human breast cancer cells inhibited their bone-metastatic potential in an experimental bone metastasis model. ${ }^{34}$ Ectopic expression of $\mathrm{ER} \alpha$ in MDA-MB-231 breast cancer cells reduced the number and volume of lung metastases when the cells were inoculated into the tail vein of nude mice. ${ }^{32}$

ESR1 has also been shown to affect cell proliferation. For example, overexpression of ESR1 in HeLa cervical cancer cells has been shown to inhibit their proliferation. ${ }^{35}$ Although modulation of ESR1 alone has shown effects on cell proliferation and tumor progression, it is likely that many effects of ESR1 are dependent on other cofactors and occur in a tissue-specific manner. Taken together, the current work and previous in vitro and in vivo studies $^{36}$ support a dual protective effect of ESR1 in reducing both cancer cell proliferation and invasion in some types of cancers.

Chung and colleagues ${ }^{37}$ recently described the requirement for estrogen receptor $\alpha$ (ESR1) in a mouse model of cervical cancer in which HPV16 E7 is expressed in the cervix under control of the human keratin 14 promoter. Specifically, their study showed that exogenous estrogen failed to promote either cervical dysplasia or carcinoma in K14E7/ER $\alpha^{-1-}$ transgenic mice. Although this finding might initially seem at odds with the data presented here, Chung et al observed that E7 expression and exogenous estrogen failed to promote atypical squamous metaplasia in the absence of $\mathrm{ER} \alpha$. The authors acknowledged that they did not demonstrate a continued role of $E R \alpha$ in the steps of tumor progression downstream of atypical squamous metaplasia. Hence, it is possible that $\mathrm{ER} \alpha$ is no longer a requirement once the critical precursor lesion develops and subsequent loss of ER $\alpha$ may actually promote tumor progression. Temporal regulation of ER $\alpha$ expression in this mouse model would be required to test this possibility.

The mechanisms underlying loss of ESR1 expression during the progression of certain types of cancer have been studied for many years. In breast cancer, the collective data indicate that ESR1 levels are likely regulated by multiple mechanisms, including transcriptional repression by other transcription factors or epigenetic modification, and/or regulation at the posttranscriptional and posttranslational levels. ${ }^{38}$ Our studies suggest multiple mechanisms likewise contribute to loss of ESR1 during cervical cancer progression.

ESR1 has a typical $\mathrm{CpG}$ island within its promoter and first exon. DNA methylation is considered a major mechanism for loss of ESR1 expression in breast cancer, as well as cancers of the prostate, lung, colorectum and hematopoietic system. ${ }^{39}$ However, based on a recent literature review, ESR1 was not found to be frequently methylated in cervical cancers. ${ }^{40}$ Although hypermethylation of ESR1 has been linked to early events in cervical carcinogenesis, ${ }^{41}$ methylation was found to occur not only in tumor samples but also in normal tissue and to increase with aging. ${ }^{20,42}$ Our bisulfite sequencing analysis demonstrated ESR1 promoter methylation in several cervical cancer cell lines, but not in primary tumors. Thus, although methylation of ESR1 is associated with reduced or absent ER expression in some cervical cell lines and tissue specimens, it probably does not account for the ER-negative status in most cases.

Our comparative gene expression analysis found that EZH2 transcripts were significantly negatively correlated 
A

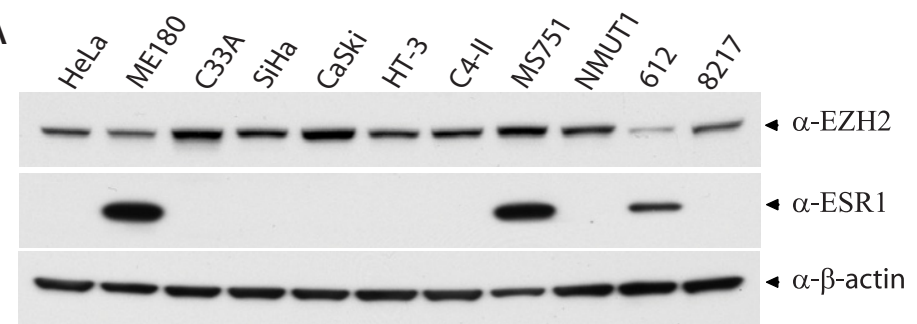

B
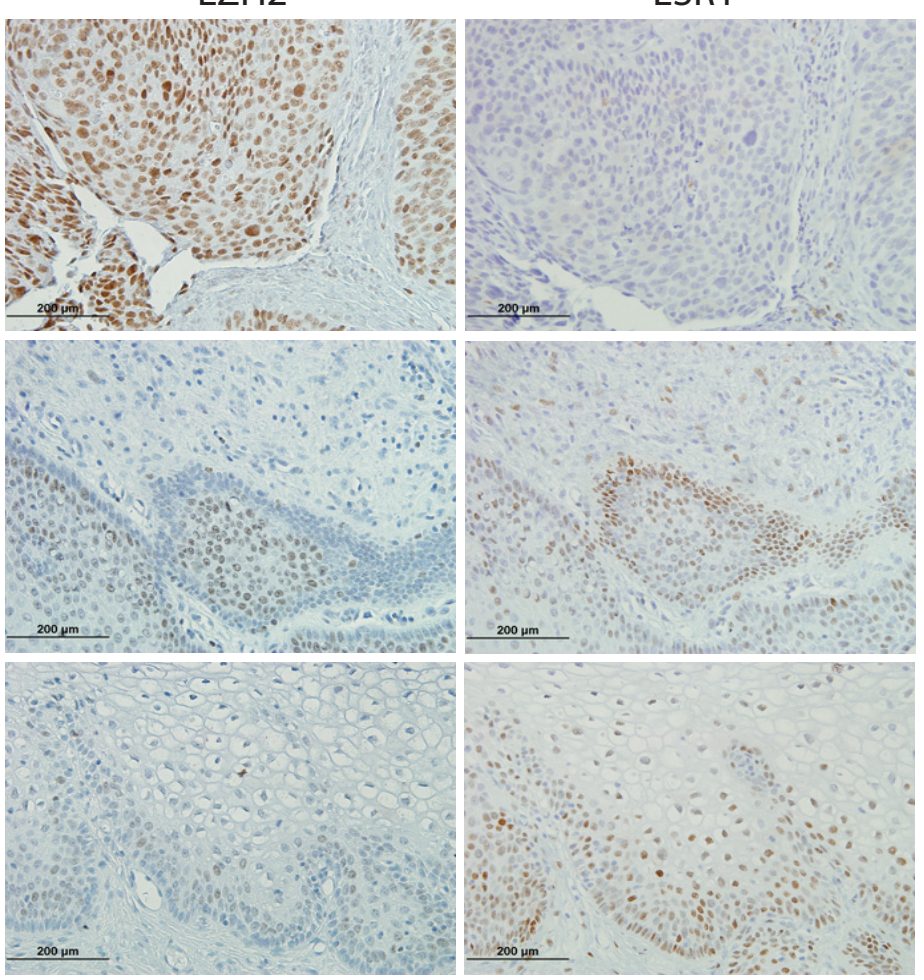

C
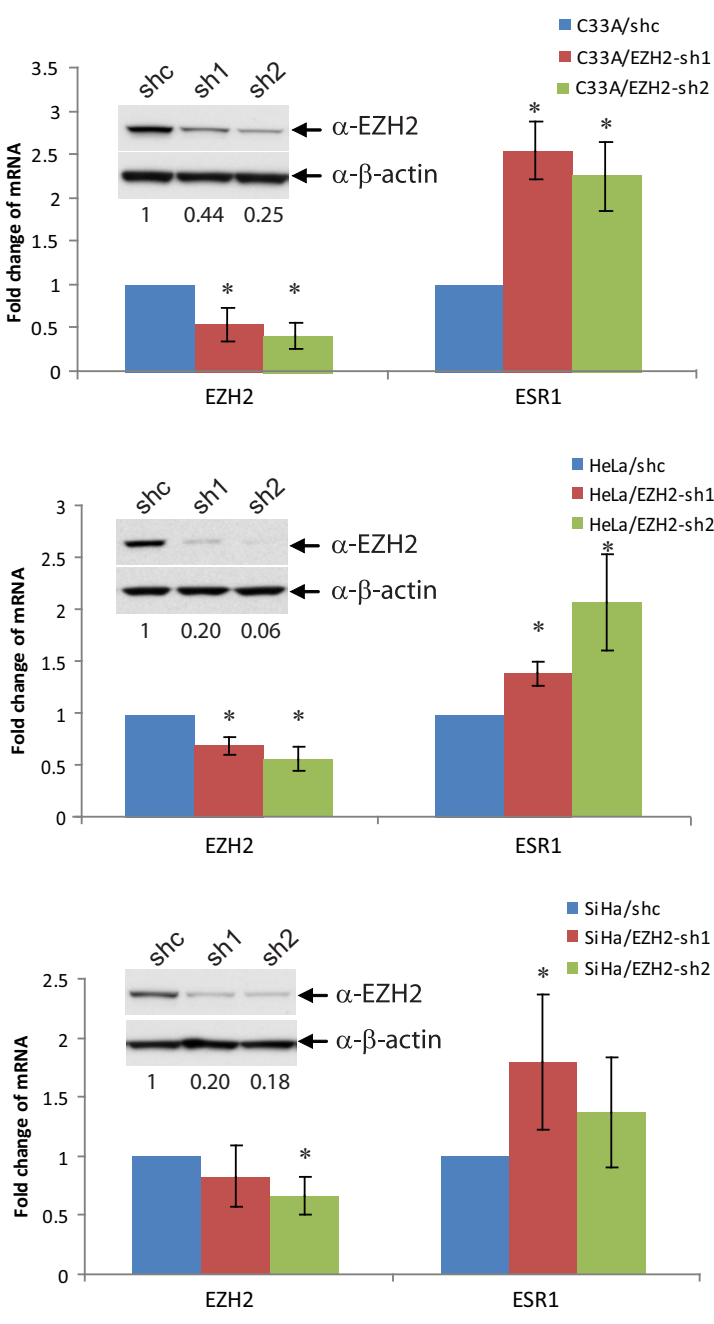

Figure 7. EZH2 is inversely correlated with ESR1 expression and partially contributes to loss of ESR1 expression. A: Western blot analysis of endogenous EZH2 and ESR1 in cervical cancer cell lines. $\beta$-actin was used as a loading control. B: Representative serial sections of cervical tissues immunohistochemically stained using anti-EZH2 and anti-ESR1 antibodies. Sections from an invasive SCC (top panels), HSIL (middle panels), and normal cervix (bottom panels) are shown. Original magnifications, $\times 200$. C: shRNA-mediated knockdown of EZH2 increases ESR1 transcript levels based on quantitative RT-PCR. RT-PCR data represent mean + SD derived from three independent experiments, each performed in duplicate and normalized to HPRT. The results are shown as fold changes relative to level in matched cells transduced with shRNA control (shc). There are significant differences ( $P<0.05$, Student's $t$-test). Western blot analysis of EZH2 and $\beta$-actin (loading control) in indicated cells after stable transduction with lentiviruses expressing two independent shRNAs (sh1, and sh2) and control shRNA (shc) is shown as an inset in each graph. The EZH2 signals obtained from the Western blot analysis were quantified with Image J program ( $h t t p: / / r s b . i n f o . n i h . g o v / i j)$ and normalized to $\beta$-actin. The ratios were compared with control shRNA (set as 1 ) indicated by the values below the blots

with ESR1 transcripts, and this negative correlation was further confirmed by immunohistochemical staining of primary cervical tissues. EZH2 is a member of the Polycomb Group (PcG) of proteins homologous to Drosophila Enhancer of Zeste, and contributes to epigenetic silencing/transcriptional repression of target genes. ${ }^{43}$ Overexpression of $\mathrm{EZH} 2$ has been observed in many types of malignancies including cervical cancers, ${ }^{28}$ and studies in breast cancer have shown a significant inverse association between high EZH2 protein expression and negative ER status. ${ }^{25}$ Shi and colleagues ${ }^{44}$ have shown that EZH2 physically interacts with ESR1 and functionally enhances transactivation of genes targeted by estrogen signaling. We wished to determine whether EZH2 transcriptionally represses ESR1 in cervical cancer cells. Ectopic expression of EZH2 in three ESR1 expressing cell lines failed to reduce either ESR1 transcripts or protein expression, but knockdown of endogenous EZH2 in three ESR1 negative cell lines partially restored ESR1 expression. Our study suggests that while EZH2 may contribute to loss of ESR1 expression during cervical carcinogenesis, like ESR1 promoter methylation, it is likely not the only factor.

Our findings add to previous studies showing that downregulation of ESR1 expression is an early alteration during the development of cervical dysplasia in cells infected by high-risk HPV types. ${ }^{45}$ We discovered tumor suppressive properties for ESR1 during cervical cancer progression, particularly during the transition from squamous intraepithelial precursor lesion to invasive carcinoma. Loss of ESR1 expression, in conjunction with other factors, enhances squamous epithelial cell invasion through the basement 
membrane and into underlying cervical stroma. Future studies will be needed to identify the downstream effectors of ESR1 that contribute to inhibition of invasion as well as the additional mechanisms that likely contribute to loss of ESR1 expression during cervical tumor progression.

\section{References}

1. Parkin DM, Bray F, Ferlay J, Pisani P: Global cancer statistics, 2002. CA Cancer J Clin 2005, 55:74-108

2. Ostor AG: Natural history of cervical intraepithelial neoplasia: a critical review. Int J Gynecol Pathol 1993, 12:186-192

3. Trimble CL, Piantadosi S, Gravitt P, Ronnett B, Pizer E, Elko A, Wilgus B, Yutzy W, Daniel R, Shah K, Peng S, Hung C, Roden R, Wu TC, Pardoll D: Spontaneous regression of high-grade cervical dysplasia: effects of human papillomavirus type and HLA phenotype. Clin Cancer Res 2005, 11:4717-4723

4. Wright TC, Jr., Massad LS, Dunton CJ, Spitzer M, Wilkinson EJ, Solomon D: 2006 consensus guidelines for the management of women with cervical intraepithelial neoplasia or adenocarcinoma in situ. Am J Obstet Gynecol 2007, 197:340-345

5. Zhai Y, Kuick R, Nan B, Ota I, Weiss SJ, Trimble CL, Fearon ER, Cho KR: Gene expression analysis of preinvasive and invasive cervical squamous cell carcinomas identifies HOXC10 as a key mediator of invasion. Cancer Res 2007, 67:10163-10172

6. Kaur P, McDougall JK: HPV-18 immortalization of human keratinocytes. Virology 1989, 173:302-310

7. Garrett LR, Perez-Reyes N, Smith PP, McDougall JK: Interaction of HPV-18 and nitrosomethylurea in the induction of squamous cell carcinoma. Carcinogenesis 1993, 14:329-332

8. De Geest K, Bergman CA, Turyk ME, Frank BS, Wilbanks GD: Differential response of cervical intraepithelial and cervical carcinoma cell lines to transforming growth factor-beta 1. Gynecol Oncol 1994, 55:376-385

9. De Geest K, Turyk ME, Hosken MI, Hudson JB, Laimins LA, Wilbanks GD: Growth and differentiation of human papillomavirus type $31 \mathrm{~b}$ positive human cervical cell lines. Gynecol Oncol 1993, 49:303-310

10. Husnjak K, Grce M, Magdic L, Pavelic K: Comparison of five different polymerase chain reaction methods for detection of human papillomavirus in cervical cell specimens. J Virol Methods 2000, 88:125-134

11. Kado S, Kawamata $Y$, Shino $Y$, Kasai T, Kubota K, Iwasaki H, Fukazawa I, Takano H, Nunoyama T, Mitsuhashi A, Sekiya S, Shirasawa $\mathrm{H}$ : Detection of human papillomaviruses in cervical neoplasias using multiple sets of generic polymerase chain reaction primers. Gynecol Oncol 2001, 81:47-52

12. Gheit T, Landi S, Gemignani F, Snijders PJ, Vaccarella S, Franceschi S, Canzian F, Tommasino M: Development of a sensitive and specific assay combining multiplex PCR and DNA microarray primer extension to detect high-risk mucosal human papillomavirus types. J Clin Microbiol 2006, 44:2025-2031

13. Hajra KM, Chen DY, Fearon ER: The SLUG zinc-finger protein represses E-cadherin in breast cancer. Cancer Res 2002, 62:1613-1618

14. Li LC, Dahiya R: MethPrimer: designing primers for methylation PCRs. Bioinformatics 2002, 18:1427-1431

15. Nonogaki H, Fujii S, Konishi I, Nanbu Y, Ozaki S, Ishikawa Y, Mori T: Estrogen receptor localization in normal and neoplastic epithelium of the uterine cervix. Cancer 1990, 66:2620-2627

16. Konishi I, Fujii S, Nonogaki H, Nanbu Y, Iwai T, Mori T: Immunohistochemical analysis of estrogen receptors, progesterone receptors, Ki-67 antigen, and human papillomavirus DNA in normal and neoplastic epithelium of the uterine cervix. Cancer 1991, 68:1340-1350

17. Fonseca-Moutinho JA, Cruz E, Carvalho L, Prazeres HJ, de Lacerda MM, da Silva DP, Mota F, de Oliveira CF: Estrogen receptor, progesterone receptor, and bcl-2 are markers with prognostic significance in CIN III. Int J Gynecol Cancer 2004, 14:911-920

18. Ottaviano YL, Issa JP, Parl FF, Smith HS, Baylin SB, Davidson NE: Methylation of the estrogen receptor gene CPG island marks loss of estrogen in human breast cancer cells. Cancer Res 1994, 54:2552-2555

19. Lapidus RG, Nass SJ, Butash KA, Parl FF, Weitzman SA, Graff JG, Herman JG, Davidson NE: Mapping of ER gene CpG island methylationspecific polymerase chain reaction. Cancer Res 1998, 58:2515-2519
20. Muller HM, Widschwendter A, Fiegl H, Goebel G, Wiedemair A, Muller-Holzner E, Marth C, Widschwendter M: A DNA methylation pattern similar to normal tissue is associated with better prognosis in human cervical cancer. Cancer Lett 2004, 209:231-236

21. Wisman GB, Nijhuis ER, Hoque MO, Reesink-Peters N, Koning AJ, Volders $H H$, Buikema HJ, Boezen HM, Hollema H, Schuuring E, Sidransky D, van der Zee AG: Assessment of gene promoter hypermethylation for detection of cervical neoplasia. Int J Cancer 2006, 119:1908-1914

22. Hori M, Iwasaki M, Shimazaki J, Inagawa S, Itabashi M: Assessment of hypermethylated DNA in two promoter regions of the estrogen receptor alpha gene in human endometrial diseases. Gynecol Oncol 2000, 76:89-96

23. Iwase H, Omoto Y, Iwata H, Toyama T, Hara Y, Ando Y, Ito Y, Fujii Y, Kobayashi S: DNA methylation analysis at distal and proximal promoter regions of the oestrogen receptor gene in breast cancers. $\mathrm{Br} J$ Cancer 1999, 80:1982-1986

24. Dhasarathy A, Kajita M, Wade PA: The transcription factor snail mediates epithelial to mesenchymal transitions by repression of estrogen receptor-alpha. Mol Endocrinol 2007, 21:2907-2918

25. Kleer CG, Cao Q, Varambally S, Shen R, Ota I, Tomlins SA, Ghosh D, Sewalt RG, Otte AP, Hayes DF, Sabel MS, Livant D, Weiss SJ, Rubin MA, Chinnaiyan AM: EZH2 is a marker of aggressive breast cancer and promotes neoplastic transformation of breast epithelial cells. Proc Natl Acad Sci USA 2003, 100:11606-11611

26. Ding L, Kleer CG: Enhancer of Zeste 2 as a marker of preneoplastic progression in the breast. Cancer Res 2006, 66:9352-9355

27. Gonzalez ME, Li X, Toy K, DuPrie M, Ventura AC, Banerjee M, Ljungman M, Merajver SD, Kleer CG: Downregulation of EZH2 decreases growth of estrogen receptor-negative invasive breast carcinoma and requires BRCA1. Oncogene 2009, 28:843-853

28. Holland D, Hoppe-Seyler K, Schuller B, Lohrey C, Maroldt J, Durst M, Hoppe-Seyler F: Activation of the enhancer of zeste homologue 2 gene by the human papillomavirus E7 oncoprotein. Cancer Res 2008, 68:9964-9972

29. Maynadier M, Nirde P, Ramirez JM, Cathiard AM, Platet N, Chambon M, Garcia M: Role of estrogens and their receptors in adhesion and invasiveness of breast cancer cells. Adv Exp Med Biol 2008, 617:485-491

30. Kurebayashi J, Otsuki T, Kunisue H, Tanaka K, Yamamoto S, Sonoo $\mathrm{H}$ : Expression levels of estrogen receptor-alpha, estrogen receptorbeta, coactivators, and corepressors in breast cancer. Clin Cancer Res 2000, 6:512-518

31. Hu K, Zhong G, He F: Expression of estrogen receptors ERalpha and ERbeta in endometrial hyperplasia and adenocarcinoma. Int J Gynecol Cancer 2005, 15:537-541

32. Garcia M, Derocq D, Freiss G, Rochefort H: Activation of estrogen receptor transfected into a receptor-negative breast cancer cell line decreases the metastatic and invasive potential of the cells. Proc Natl Acad Sci USA 1992, 89:11538-11542

33. Ali SH, O'Donnell AL, Mohamed S, Mousa S, Dandona P: Overexpression of estrogen receptor-alpha in the endometrial carcinoma cell line Ishikawa: inhibition of growth and angiogenic factors. Gynecol Oncol 2004, 95:637-645

34. Bandyopadhyay A, Wang L, Chin SH, Sun LZ: Inhibition of skeletal metastasis by ectopic ERalpha expression in ERalpha-negative human breast cancer cell lines. Neoplasia 2007, 9:113-118

35. Maminta ML, Molteni A, Rosen ST: Stable expression of the human estrogen receptor in HeLa cells by infection: effect of estrogen on cell proliferation and c-myc expression. Mol Cell Endocrinol 1991, 78:61-69

36. Platet N, Cathiard AM, Gleizes M, Garcia M: Estrogens and their receptors in breast cancer progression: a dual role in cancer proliferation and invasion. Crit Rev Oncol Hematol 2004, 51:55-67

37. Chung SH, Wiedmeyer K, Shai A, Korach KS, Lambert PF: Requirement for estrogen receptor alpha in a mouse model for human papillomavirusassociated cervical cancer. Cancer Res 2008, 68:9928-9934

38. Parl FF: Multiple mechanisms of estrogen receptor gene repression contribute to ER-negative breast cancer. Pharmacogenomics J 2003, 3:251-253

39. Berger J, Daxenbichler G: DNA methylation of nuclear receptor genes-possible role in malignancy. J Steroid Biochem Mol Biol 2002, $80: 1-11$

40. Wentzensen N, Sherman ME, Schiffman M, Wang SS: Utility of meth- 
ylation markers in cervical cancer early detection: appraisal of the state-of-the-science. Gynecol Oncol 2009, 112:293-299

41. Henken FE, Wilting SM, Overmeer RM, van Rietschoten JG, Nygren AO, Errami A, Schouten JP, Meijer CJ, Snijders PJ, Steenbergen RD: Sequential gene promoter methylation during HPV-induced cervical carcinogenesis. Br J Cancer 2007, 97:1457-1464

42. Ahuja N, Issa JP: Aging, methylation and cancer. Histol Histopathol 2000, 15:835-842

43. Varambally S, Dhanasekaran SM, Zhou M, Barrette TR, Kumar-Sinha C, Sanda MG, Ghosh D, Pienta KJ, Sewalt RG, Otte AP, Rubin MA,
Chinnaiyan AM: The polycomb group protein EZH2 is involved in progression of prostate cancer. Nature 2002, 419:624-629

44. Shi B, Liang J, Yang X, Wang Y, Zhao Y, Wu H, Sun L, Zhang Y, Chen $Y$, Li R, Zhang Y, Hong M, Shang Y: Integration of estrogen and Wnt signaling circuits by the polycomb group protein EZH2 in breast cancer cells. Mol Cell Biol 2007, 27:5105-5119

45. Bekkers RL, van der Avoort IA, Melchers WJ, Bulten J, de Wilde PC, Massuger LF: Down regulation of estrogen receptor expression is an early event in human papillomavirus infected cervical dysplasia. Eur J Gynaecol Oncol 2005, 26:376-382 